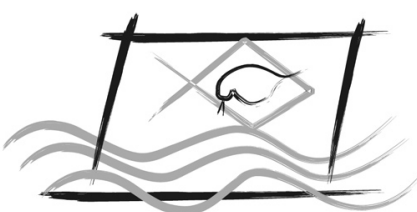

ECOTOX - BRASIL

\title{
Metallothionein in the pond perch Diplectrum radiale (Teleostei) as a biomarker of pollution in Guanabara Bay estuary, Brazil
}

\author{
D.R. Silva-Junior ${ }^{1 *}$, V.S. Gomes ${ }^{2}$, A.R. Linde-Arias ${ }^{2} \&$ M. Vianna ${ }^{1}$ \\ ${ }^{1}$ Universidade Federal do Rio de Janeiro, Institute of Biology, Department of Marine Biology, Lab. of Fishery Biology and Technology. \\ CCS, B1. A, 21949-900, Cidade Universitária, Ilha do Fundão, Rio de Janeiro, Brazil. \\ ${ }^{2}$ Fundação Oswaldo Cruz, Escola Nacional de Saúde Pública Sérgio Arouca, Laboratory of Toxicology. Avenida Leopoldo Bulhões, 1480, \\ Bonsucesso, Rio de Janeiro, Brazil.
}

(Received June 16, 2010; Accept October 14, 2011)

\begin{abstract}
Guanabara Bay is a semi-closed tropical bay located in the center of metropolitan Rio de Janeiro. The ecological integrity of this system has a spatial gradient, with better environmental conditions near the mouth than in the inner bay. The objectives of this study were to monitor the exposure of the pond perch Diplectrum radiale (Perciformes; Serranidae) to metal pollution, using metallothionein as a specific biomarker, and to detect spatial differences in metal contamination in this large water body. The effects of biological factors (allometric condition factor, size, weight, and reproductive stage) and spatial variations on MT levels were also investigated among sampling sites. The results revealed intraspecific sources of variation influencing MT expression. Therefore, it was not possible to use MT as a sensitive biomarker to distinguish heavy metal pollution among sites within this bay. The spatial heterogeneity of metal bioavailability and the probable mobility of individual fish contributed to those findings. However, the pond perch can still be considered a good target organism to evaluate the effects of metal contamination through comparison with other estuarine ecosystems on the Brazilian coast.
\end{abstract}

Key words: estuary, Guanabara Bay, metallothionein, teleost

\section{Metalotioneína em michole Diplectrum radiale (Teleostei) como biomarcador para poluição no sistema estuarino da Baía de Guanabara, Brasil}

\section{Resumo}

A Baía de Guanabara é um ecossistema estuarino, semi-fechado e tropical localizado no centro da região metropolitana do Rio de Janeiro. Sua integridade ecológica possui um gradiente espacial o qual apresenta melhores condições ambientais próximas a sua entrada do que em suas porções interiores. Os objetivos do presente estudo são de avaliar a exposição do teleósteo michole, Diplectrum radiale (Perciformes; Serranidae), à contaminação por metal pesado através do uso da metalotioneína (MT) como biomarcador específico e identificar possíveis diferenças espaciais em termos de contaminação por metais pesados neste ambiente. Os efeitos dos fatores biológicos (fator de condição alométrico, tamanho, peso e estágio reprodutivo) e da variabilidade espacial sobre as concentrações de MT também foram investigados entre as áreas de amostragem. Os resultados revelaram fontes de variabilidade intraespecíficas na expressão da MT. Dessa forma, não foi possível empregar a MT como biomarcador para distinguir a poluição por metal pesado entre as estações amostradas dentro deste ambiente. A heterogeneidade espacial dos metais na fase biodisponível e a provável mobilidade dos peixes entre as estações contribuíram para os resultados incluindo mais fontes de variabilidade nos dados. Apesar disso, o michole pode ser considerado uma espécie alvo potencial para avaliação dos efeitos da contaminação por metais pesados através da comparação dos presentes resultados com outros ecossistemas estuarinos da costa brasileira.

Palavras chave: Estuário, Baía de Guanabara, Metalotioneína, Teleósteo.

*Corresponding author: Demarques R. da Silva Junior, e-mail: demarques@biologia.ufrj.br 


\section{INTRODUCTION}

Aquatic ecosystems are susceptible to a variety of pollutants, leading to eutrophication, loss of biodiversity, and habitat destruction (Raposa et al., 2003). These alterations tend to manifest only after longer periods of time, and are preceded by biochemical and physiological alterations that move from one organization level to another and eventually throughout the ecosystem (van der Oost et al., 2003).

Detection and assessment of alterations, particularly at low or sublethal concentrations, provide an early warning of future, more serious ecological costs (Livingstone, 1993; Linde-Arias et al., 2008). This approach has been widely suggested (Cajaraville et al., 2000) through the evaluation of molecular, cellular, and physiological responses, known as biomarkers.

As a valuable tool for monitoring programs, metallothionein (MT) has usually been employed to monitor the exposure of a variety of organisms (e.g., mollusksand teleost fishes) to metal ions as a specific biomarker. Due to potential deleterious consequences that include genetic mutation, biochemical and physiological alterations, cellular damage, and depletion of natural resources, such as water supply and fisheries, the assessment of metal contamination is of ecological and health concern worldwide (Goldberg, 1975). MT consists of a cysteine-rich heat-stable protein with low molecular weight found in the cytosol of different tissues from all organisms including marine species (Roesijadi, 1992). Physiologically, MT participates in metal regulation of essential ions and metal sequestering of both essential (when in excess) and non-essential ions, therefore being associated with the detoxification function (Roesijadi, 1992; Hamza-Chaffai et al., 1997; van der Oost et al., 2003).

However, MT is recognized to oscillate due to numerous environmental factors, especially in naturally stressful environments such as estuaries, which are under the influence of tidal currents, turbidity, and temperature and salinity gradients (Legras et al., 2000). Biological factors such as sex, size, and maturity stages are also supposed to influence organisms' outputs. These sources of variation must be assessed during the first stages of investigation, in order to avoid misleading ecotoxicological interpretations.

The present study investigated the use of metallothionein to evaluate the impacts of heavy-metal contamination in Guanabara Bay, one of the most important estuarine ecosystems on the Brazilian coast, which receives inputs of a mixture of pollutants, including heavy metals. To achieve this objective, a spatial approach was used, and biological factors of the pond perch Diplectrum radiale (Perciforme; Serranidae) were previously investigated to assess the utility of this species as a sentinel.

\section{MATERIALS AND METHODS}

\section{Study area and choice of sites}

Guanabara Bay is a semi-closed tropical bay located on the southeast coast of Brazil, in the center of metropolitan Rio de Janeiro, an important urban and industrial center (Fig. 1). There are more than 12,000 industries in the drainage basin account for $25 \%$ of the organic pollutants released into the bay. The major sources of pollution in this bay result from diverse industrial activity in the surrounding area, in addition to shipyards, oil refineries, and domestic discharges (Kjerfve et al., 1997). Therefore, Guanabara Bay receives a mixture of pollutants, including heavy metals that are widely spread in the whole ecosystem (see Perin et al., 1997; Baptista Neto et al., 2000; Fonseca et al., 2009).

The pollution pattern of this system has a gradient (see Mayr et al., 1989; Kjerfve et al., 1997). The northwestern side is in a state of advanced deterioration, mainly due to its shallow depths that contribute to limited water circulation, and to the presence of the highly urbanized and industrialized drainage basin composed of the São João de Meriti River and the Sarapuí River (Baptista Neto et al., 2000). On the opposite shore, the northeastern portion is better preserved due to the integrity of the drainage basin of the Guapimirim Environmental Protection Area. The central channel as well as the mouth of the estuary have the best environmental integrity, due to tidal currents that regularly renew the water. This general pattern agrees with studies (e.g., Villac et al., 1991) supporting the selection of the sampling sites (Fig. 1).

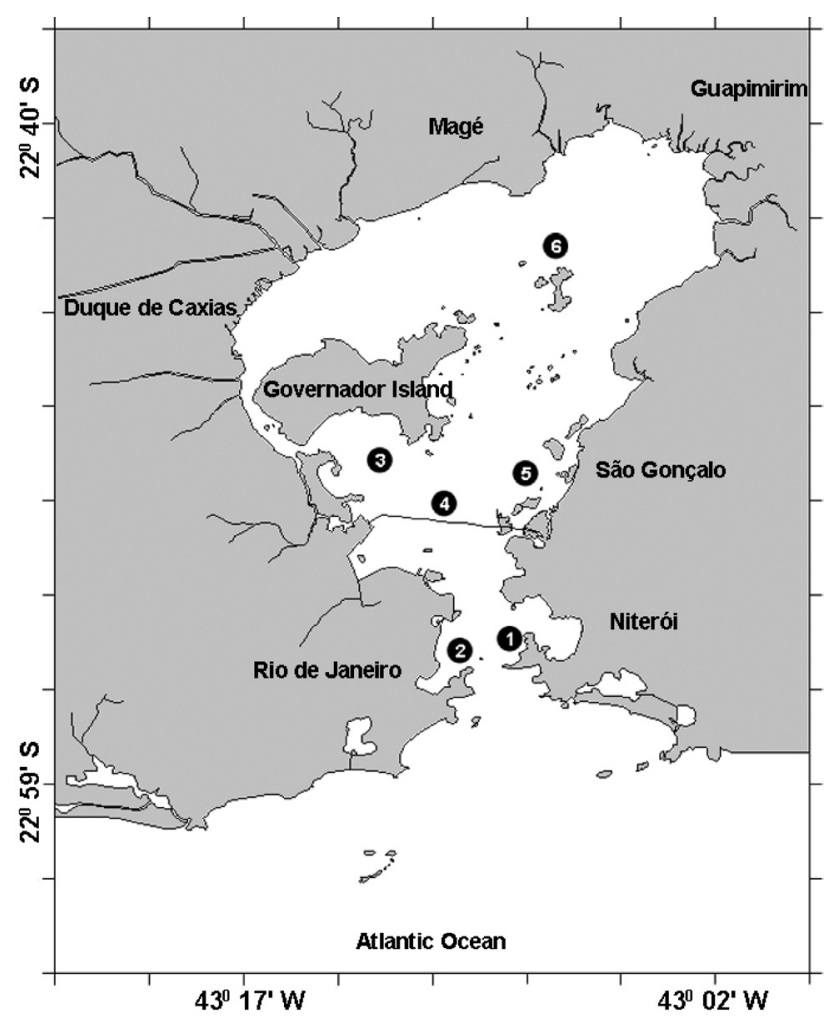

Figure 1 - Sampling sites in Guanabara Bay. Scale in UTM. 


\section{Specimens}

Specimens of the pond perch Diplectrum radiale were caught in monthly trawls in 2005 and 2006. Fish were labeled by site and stored at $-10^{\circ} \mathrm{C}$. All individuals had their total length and total weight measured to the nearest $0.1 \mathrm{~cm}$ and $0.1 \mathrm{~g}$, respectively. The size of first sexual maturity $\left(\mathrm{L}_{50}-\right.$ when $50 \%$ of the individuals are mature) was considered to be $13 \mathrm{~cm}$ (Meurer, 2000). The allometric condition factor (ACF) was employed as a gross index for indication of the general effects of pollution in fishes. It generically represents the condition of the whole body since provides information on energy reserves (growth and reproduction). However, it is quite general and non-specific being affected by non-pollutant factors (e.g. season, disease and nutritional level). Even so, the low cost and the rapidity still make it a valuable tool (van der Oost et al., 2003).

\section{Tissue preparation and MT determination}

Hepatic tissues were analyzed because of the liver's role in metal detoxification (e.g., Ploetz et al., 2007). Hepatic samples were individually homogenized in 3 vol of $20 \mathrm{mM}$ TRIS (Merck), 0.5 M sucrose (Dinâmica), pH 8.6. The homogenates were centrifuged in a Hitachi CR21E centrifuge for $20 \mathrm{~min}$ at $30,000 \mathrm{~g}$ and $4^{\circ} \mathrm{C}$ to provide a supernatant (S50) that corresponds to the cytosolic fraction. A $100-\mu \mathrm{L}$ aliquot of the cytosolic fraction was diluted in $10 \mathrm{vol}$ of $0.9 \% \mathrm{NaCl}$ (Merck) and then heat-treated at $70^{\circ} \mathrm{C}$ for 10 min (Erk et al. 2002). Supernatants were then centrifuged at $30,000 \mathrm{~g}$ for 20 $\min$ at $4^{\circ} \mathrm{C}$ (HT S50).

MT levels were determined in the heat-treated cytosolic fractions (HT S50) by differential pulse polarography (DPP; Metrohm VA663) following the modified Brdićka procedure (Raspor et al. 2001). During the procedure, HT S50 solutions were maintained at $<5^{\circ} \mathrm{C}$ and deaerated with nitrogen. MT concentrations were calculated from a linear calibration performed with commercial MT rabbit liver, purity $>95 \%$ (Bestenbalt LLC). MT levels are expressed as $\mu \mathrm{g} \mathrm{g}^{-1}$ of wet mass.

\section{Statistical methods}

All statistical analyses were carried out using a standard statistical package (Statistica 7.1), including descriptive statistics, linear regression analysis (effects of ACF, length, and weight on MT levels) and analysis of variance (ANOVA) (spatial dissimilarities of mean length, ACF, and MT) (Zar, 1996). Posthoc Tukey tests were used to determine statistical differences between means. Data are presented as mean $\pm \mathrm{SD}$, and the significance level adopted was $95 \%(\alpha=0.05)$ for all tests.

\section{RESULTS}

In this study, 52 specimens of pond perch were investigated for MT levels and biological parameters, as presented in Table 1. The ACF did not differ among sites, and no correlation was observed with MT levels (Fig. 2a). The total length and weight showed significant negative correlations with MT (Fig. $2 b$ and 2c). Mean values of MT statistically differed between juveniles and adults (Fig. 3). Finally, hepatic MT concentrations from pond perch caught at the different sampling sites were not statistically different (Fig. 4).

Table 1 - Biological parameters of Diplectrum radiale from the different sampling sites in Guanabara Bay

\begin{tabular}{lcccc}
\hline $\begin{array}{l}\text { Sampling } \\
\text { site }\end{array}$ & $\mathrm{N}$ & Length $(\mathrm{cm})$ & Weight $(\mathrm{g})$ & $\begin{array}{c}\text { Allometric condition } \\
\text { factor }\end{array}$ \\
\hline 1 & 9 & $12.5 \pm 2.9$ & $\begin{array}{c}31.0 \pm \\
29.9\end{array}$ & $0.57 \pm 0.03$ \\
& & & $\begin{array}{c}43.7 \pm \\
15.6\end{array}$ & $0.55 \pm 0.03$ \\
2 & 10 & $14.5 \pm 1.6$ & & \\
& & & & \\
3 & 8 & $13.2 \pm 1.3$ & $29.5 \pm 9.9$ & $0.52 \pm 0.04$ \\
4 & 8 & $16.1 \pm 2.0$ & $\begin{array}{c}61.1 \pm \\
23.1\end{array}$ & $0.54 \pm 0.04$ \\
5 & 10 & $13.5 \pm 2.5$ & $37.2 \pm$ & $0.53 \pm 0.04$ \\
6 & 7 & $13.7 \pm 1.5$ & $34.8 \pm$ & $0.54 \pm 0.07$ \\
\hline
\end{tabular}

Data are expressed as mean $\pm \mathrm{SD}$. Number of samples (N).

\section{DISCUSSION}

The influences of biological factors (e.g., size, weight, age, reproductive stage, and sex) on metallothionein concentration have been extensively investigated by several investigators in numerous organisms (e.g., Hamza-Chaffai et al., 1997). An ideal situation is the absence of dependence between these factors, so that the biomarker variability responds only to pollutant levels. In other words, the selection of target species involves the reduction of as many intraspecific sources of variation as possible.

The selection of the organism is a crucial step for the study, and is based on suggested biological features such as high relative abundance, accessibility, longevity, and occupation of different trophic levels (van der Oost et al., 2003). Considering these aspects, $D$. radiale is a native tropical species with ecological characteristics that make it vulnerable to heavy metal contamination. It is a carnivore, demersal, and hermaphroditic, and has a restricted homerange (Bortone, 1977; Figueiredo \& Menezes, 1980), and is therefore a good candidate to be used as a sentinel species in this particular case.

Based on the general pattern of pollution in Guanabara Bay as described above, it was expected that sites 3, 5, and 6 would show lower values of condition factor, as this parameter is considered a gross index that indicates the health condition of fish, and can be influenced by pollution (van der Oost et al., 2003). However, the initial investigations revealed that the allometric condition factor was not sensitive enough to distinguish general effects of pollution within sites in Guanabara Bay. This result may be a consequence of the relatively low number of specimens from each site. 
Furthermore, length and weight affected pond perch MT levels. As previously mentioned, this is not the best scenario for ecotoxicological investigations that must deal with additional sources of variation. We believe that this finding was an artificial result of an unbalanced sampling of length ranges, due to the smaller number of individuals larger than 15 $\mathrm{cm}$. This is a reasonable hypothesis, given that the values of $\mathrm{R}^{2}$ for both regressions were low (Fig. 2). Usually, specimens of $D$. radiale caught in estuarine environments are juveniles (Meurer, 2000), a characteristic of the species that helps to explain the smaller number of adults collected.

Sexual maturation is another biological process that involves physiological changes, especially in terms of energy allocation (Vazzoler, 1996), a situation that could lead to variation in MT expression. Again, the pond perch MT levels appeared to be influenced by maturation processes, adding another variable to be understood in the assessment of spatial metal exposure within sites. However, a large standard deviation was observed for this analysis, and therefore this result should be appraised with care. Additionally, the continuous reproductive period of pond perch (Meurer, 2000) must be considered, since it eliminates the possible interference of seasonal aspects of reproduction. Nevertheless, it would be helpful to carry out further investigations on the effects of maturity stages of this species on its MT levels.

Lastly, the central point of the study concerning the spatial assessment of metal contamination through the use of MT as a biomarker was investigated, and no difference was apparent in MT levels among sites. Considering the prior assumption that a gradient of metal contamination exists in Guanabara Bay, this was an unexpected result. Still, it can be explained by the fact that metals associated with the sediment are distributed in heterogeneous patches configured by different elements (Perin et al., 1997; Baptista Neto et al., 2000). The characteristics of MT binding and be induced by numerous metals such as $\mathrm{Ag}, \mathrm{Cd}, \mathrm{Cu}$, and $\mathrm{Hg}$ may have influenced the absence of differentiation among locations.

Another possible factor that could have affected this result is the mobility of individuals. Although this species is considered to have a small home range, it is reasonable to expect that individuals could move from the mouth to the inner part of the bay, because the pond perch is euryhaline. Therefore, it is not possible to guarantee that individuals reside in the particular location in the bay where they were caught.

Although it was not possible to distinguish local metal pollution within Guanabara Bay using MT, this does not disqualify Diplectrum radiale as a possible sentinel species, because it can reflect the level of metal contamination of the bay as a whole. Thus these results can be compared to other, similar bays on the Brazilian coast. Contrasts will probably be found when comparisons are made with less-disturbed ecosystems. If not, the present information itself can be a starting point for a temporal monitoring program, tracking the evolution of metal contamination in this ecosystem. This last possibility is of utmost importance in view of the development of a governmental remediation program for
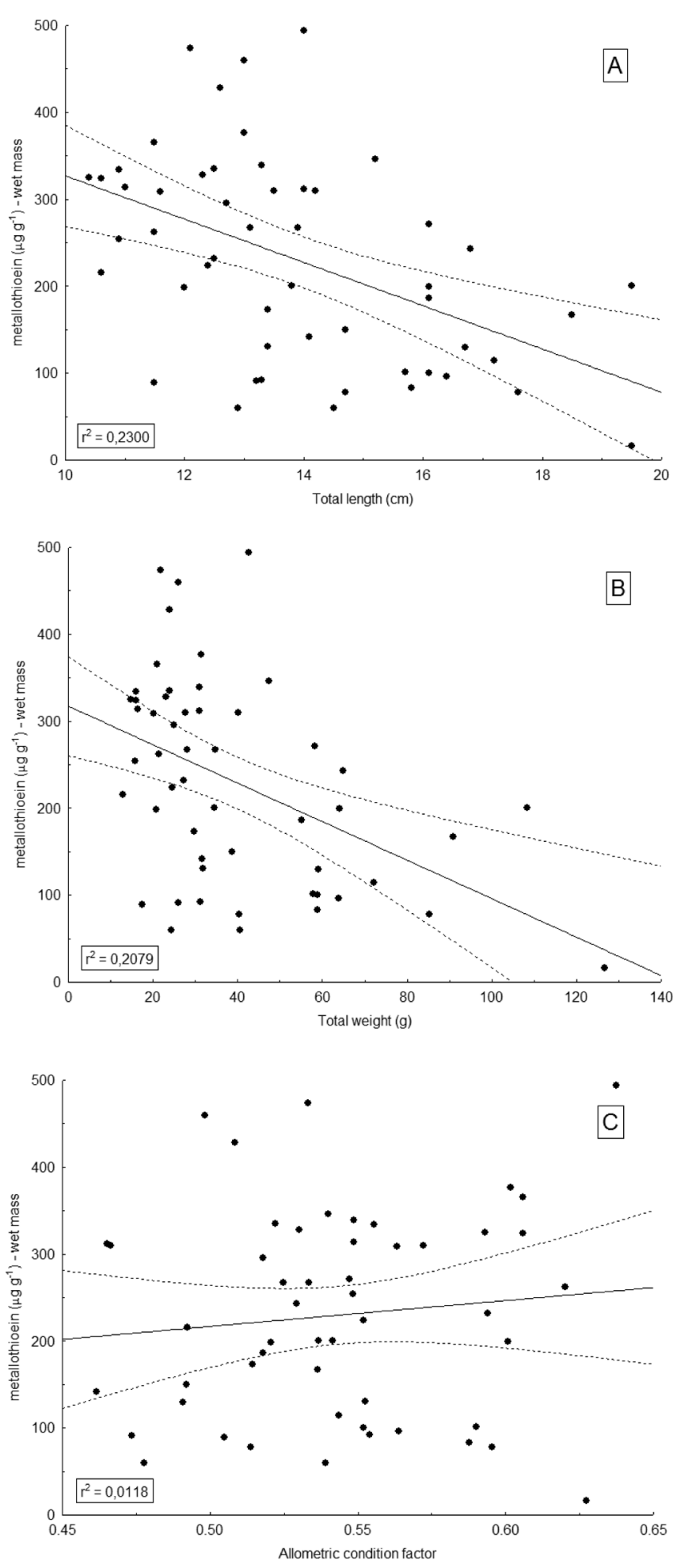

Figure 2 - Influence of total length (A), weight (B), and allometric condition factor $(\mathrm{C})$ on hepatic metallothionein concentrations of Diplectrum radiale in Guanabara Bay

this bay, where dredging activities are planned. All of these are promising approaches to provide information to support management actions.

In conclusion, considering further important criteria suggested in the literature (see Burger et al., 2006), Diplectrum radiale is a feasible target species to evaluate 


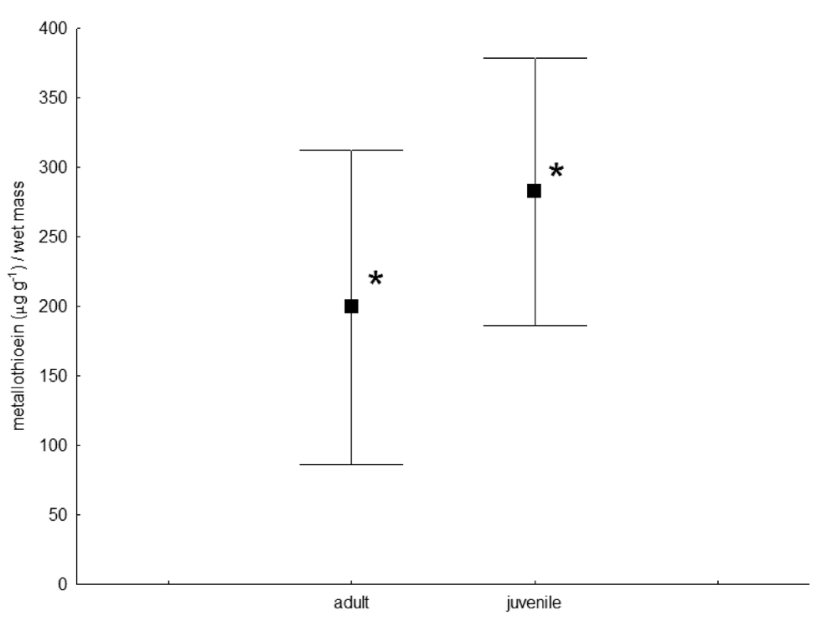

Figure 3 - Levels of hepatic metallothionein of Diplectrum radiale from the different size groups in Guanabara Bay. Values are mean $\pm \mathrm{SD} . *=$ Means statistically differ. Data are expressed as $\mu \mathrm{g} \mathrm{g}^{-1}$ liver

metal contamination. This fish has a longer lifespan than other groups, is accessible, belongs to higher trophic levels, and has commercial importance as a fishery resource. Because of various sources of variation, it was not possible to establish that MT is a sensitive biomarker to distinguish heavy metal pollution within Guanabara Bay. However, pond perch MT levels can still be useful, indicating the level of metal contamination of the bay as a whole, and allowing comparisons with other estuarine ecosystems on the Brazilian coast.

\section{REFERENCES}

BAPTISTA NETO, J. A., SMITH, B. J. \& MCALLISTER, J. J., 2000, Heavy metal concentrations in surface sediments in a nearshore environment, Jurujuba Sound, Southeast Brazil. Environ. Pollut., 109: 1-9. DOI: 10.1016/S0269-7491(99)00233-X.

BORTONE, S. A., 1977, Gonad morphology of the hermaphroditic fish Diplectrum pacificum (Serranidae). Copeia, 3: 448-453.

BURGER, J., GOCHFELD, M. \& JEWETT, S., 2006, Selecting species for marine assessment of radionuclides around Amchitka: planning for diverse goals and interests. Environ. Monit. Assess., 123: 371-391. DOI: 10.1007/s10661-006-9203-z

CAJARAVILLE, M. P., BEBIANNO M. J., BLASCO J., PORTE C., SARASQUETE C. \& VIARENGO A., 2000, The use of biomarkers to assess the impact of pollution in coastal environments of the Iberian Peninsula: a practical approach. Sci. Total Environ., 247(2-3): 295-311. DOI: 10.1016/S00489697(99)00499-4.

ERK, M., IVANKOVIĆ, D., RASPOR, B. \& PAVIČIĆ, J., 2002, Evaluation of different purification procedures for the electrochemical quantification of mussel metallothioneins. Talanta, 57: 1211-1218. DOI: 10.1016/S0039-9140(02)00239-4.

FIGUEIREDO, J. L. \& MENEZES, N. A., 1980, Manual de peixes marinhos do Sudeste do Brasil Teleostei (2). Museu de Zoologia da Universidade de São Paulo, São Paulo, 90 p.

FONSECA, E. M., BAPTISTA NETO, J. A., CRAPEZ, M. C., MCALLISTER, J. J., FERNANDEZ, M. A. \& BISPO, M. G., 2009, Bioavailability of heavy metals in Guanabara Bay, Rio de Janeiro (Brazil). J. Coast. Res., 56: 802-806.

GOLDBERG, E. D., 1975, The mussel watch - a first step in global marine monitoring. Mar. Poll. Bull., 6: 111.

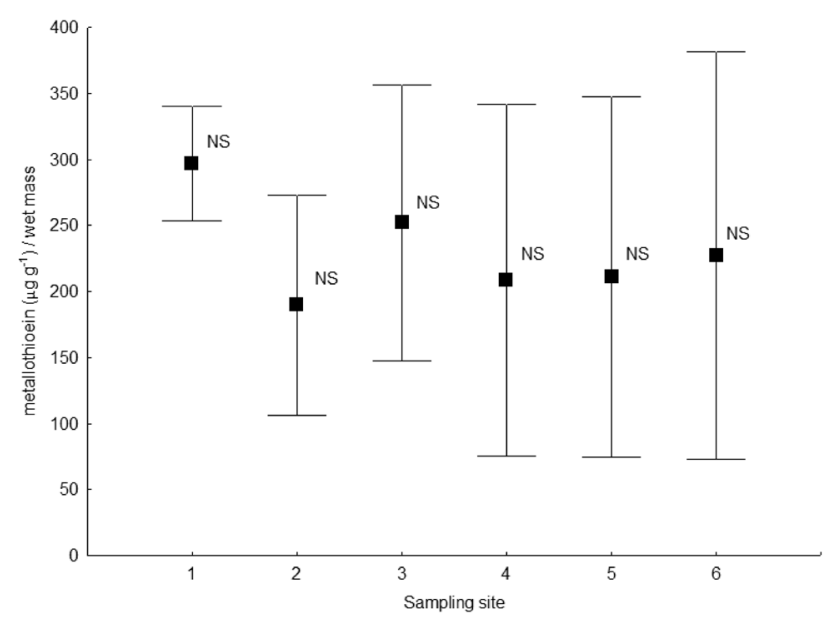

Figure 4 - Levels of hepatic metallothionein of Diplectrum radiale from the different sampling sites in Guanabara Bay. Values are mean \pm SD. NS $=$ Not Significant / Means statistically do not differ. Data are expressed as $\mu \mathrm{g} \mathrm{g}^{-1}$ liver

HAMZA-CHAFFAI, A., AMIARD-TRIQUET C. \& EL ABED, A., 1997, Metallothionein like protein: is it an efficient Biomarker of metal contamination? A case study based on fish from the Tunisian coast. Arch. Environ. Contam. Toxicol., 33: 53-62. DOI: $10.1007 / \mathrm{s} 002449900223$.

KJERFVE, B., RIBEIRO, C. H. A., DIAS, G. T. M., FILIPPO, A. M., \& QUARESMA, V. S., 1997, Oceanographic characteristics of an impacted coastal bay: Baía de Guanabara, Rio de Janeiro, Brazil. Cont. Shelf Res., 17(3): 1609-1643. DOI: 10.1016/S02784343(97)00028-9.

LEGRAS, S., MOUNEYRAC, C., AMIARD, J. C., AMIARDTRIQUET, C. \& RAINBOWN, P. S., 2000, Changes in metallothionein concentrations in response to variation in natural factors (salinity, sex, weight) and metal contamination in crabs from a metal-rich estuary. J. Exp. Mar. Biol. Ecol., 246: 259-279. DOI: 10.1016/S0022-0981(99)00187-2.

LINDE-ARIAS, A. N., INÁCIO, A. F., NOVO, L. A., ALBURQUERQUE, C. \& MOREIRA, J. C., 2008, Multibiomarker approach in fish to assess the impact of pollution in a large Brazilian river, Paraíba do Sul. Environ. Pollut., 156: 974-979. DOI: 10.1016/j.envpol.2008.05.006.

LIVINGSTONE, D. R., 1993, Biotechnology and pollution monitoring: use of molecular biomarkers in the aquatic environment. J. Chem. Technol. Biotechnol., 57: 195-211. DOI: 10.1002/chin.199339362.

MAYR, L. M., TENENBAUM, D. R., VILLAC, M. C., PARANHOS, R., NOGUEIRA, C. R., BONECKER, S. L. C. \& BONECKER, A. C. T., 1989, Coastlines of Brazil. American society of Civil Engineers, Nova York, 124-138 p.

MEURER, B. C., 2000, Estrutura populacional de Diplectrum radiale e D. formosum - Pisces, Serranidae - da Baía da Ribeira, Angra dos Reis, Rio de Janeiro, Brasil. Master Thesis. Universidade Santa Úrsula, Rio de Janeiro.

PERIN, G., FABRIS, R., MANENTE, S., REBELLO WAGENER, A., RAMACHER, C. \& SCOTTO, S., 1997, A five-year study on the heavy-metal pollution of Guanabara Bay sediments (Rio de Janeiro, Brazil) and evaluation of the metal bioavailability by means of geochemical speciation. Water Res., 31(12): 3017 3028. DOI: 10.1016/S0043-1354(97)00171-1.

PLOETZ, D. M., FITTS, B. E. \& RICE, T. M., 2007, Differential accumulation of heavy metals in muscle and liver of a marine fish, (king mackerel, Scomberomorus cavalla Cuvier) from the Northern Gulf of Mexico, USA. Bull. Environ. Contam. Toxicol., 
78: 134-137. DOI: 10.1007/s00128-007-9028-7.

RAPOSA, K. B., ROMAN, C. T. \& HELTSHE, J. F., 2003, Monitoring nekton as a bioindicator in shallow estuarine habitats. Environ. Monit. Assess., 81(1-3): 239-255.

RASPOR, B.,PAIĆ, M.\& ERK, M., 2001, Analisys of metallothionein by the midified Brdička procedure. Talanta, 55: 109-115. DOI: 10.1007/s00128-007-9028-7.

ROESIJADI, G., 1992, Metallothioneins in metal regulation and toxicity in aquatic animals. Aquat. Toxicol., (22): 81-114. DOI: 10.1016/0166-445X(92)90026-J.

VAN DER OOST, R., BEYER, J. \& VERMEULEN, N. P. E., 2003,
Fish bioaccumulation and biomarkers in environmental risk assessment: a review. Environ. Toxicol. Pharm., 13: 57-149. DOI: 10.1016/S1382-6689(02)00126-6.

VAZZOLER, A. E. A., 1996, Biologia da reprodução de peixes teleósteos: teoria e prática. EDUEM, Maringá, 169 p.

VILLAC, M. C., MAYR, L. M., TENENBAUN, D. R. \& PARANHOS, R., 1991, Sampling strategies proposed to monitor Guanabara Bay, RJ, Brazil. Proceedings of the Seventh Symposium on Coastal and Ocean Management, California, 1168:1182.

ZAR, J. H., 1996, Bioestatistical analysis. Prentice-Hall, New Jersey, $718 \mathrm{p}$. 